\title{
Morphophysiology of guava cv. Paluma with water of different salt concentrations and proline doses
}

\section{Morfofisiologia de goiabeira cv. Paluma com água de diferentes concentrações salinas e doses de prolina}

\author{
Luana Lucas de Sá Almeida Veloso ${ }^{1 *}$; Reginaldo Gomes Nobre ${ }^{2}$; Cristiane Milenne \\ Alves de Souza ${ }^{3}$; Reynaldo Teodoro de Fatima ${ }^{3}$; Leandro de Pádua Souza ${ }^{1}$; Jutahy \\ Jorge Elias ${ }^{3}$; Felipe Luênio de Azevêdo ${ }^{3}$; João Batista dos Santos ${ }^{4}$
}

\begin{abstract}
Quantitative and qualitative limitations of water resources in Northeast Brazil, besides the excessive use of fertilizers without criteria related to soil analysis and crop needs, has called the attention for studies on techniques that allow saline waters to be used in agriculture. This study aimed to evaluate physiological and growth responses of grafted guava plants, cv. Paluma, as a function of irrigation with saline water and foliar applications of proline. The experiment was carried out in protected environment in Pombal - PB, Brazil, in a randomized block design in $4 \times 4$ factorial scheme, with three replicates, and treatments consisted of four levels of irrigation water electrical conductivity $-\mathrm{ECw}(0.3 ; 1.0 ; 1.7$ and $\left.2.4 \mathrm{dS} \mathrm{m}^{-1}\right)$ associated with four doses of proline $\left(0,5,10\right.$ and $\left.15 \mathrm{mmol} \mathrm{L}^{-1}\right)$. Grafted plants of guava cv. Paluma can be grown using water with $\mathrm{ECw}$ of $1.1 \mathrm{dS} \mathrm{m}^{-1}$ since it led to acceptable mean reduction of $10 \%$ in growth and physiological activity. Mean proline dose of $8 \mathrm{mmol} \mathrm{L}^{-1}$ leads to increase in the number of leaves and dry matter accumulation. The interaction between proline doses and water salinity levels did not affect either growth or physiology of grafted plants of guava cv. Paluma, at 101 days after transplanting.
\end{abstract}

Key words: Psidium guajava. Salinity and amino acid.

\section{Resumo}

As limitações quantitativas e qualitativas dos recursos hídricos do Nordeste Brasileiro, além uso abusivo de adubos sem critérios de análise de solo e da necessidade da cultura, têm despertado o interesse para estudos de técnicas que viabilizem o uso de água salinas na agricultura. Objetivou-se avaliar as respostas fisiológicas e de crescimento de plantas enxertadas de goiabeiras cv. Paluma, em função da irrigação com águas salinas e aplicações foliares de prolina. $\mathrm{O}$ experimento foi desenvolvido em ambiente protegido em Pombal - PB. Utilizou-se o delineamento experimental de blocos casualizados em esquema fatorial de $4 \times 4$, com três repetições, sendo os tratamentos compostos de quatro condutividades elétricas da água de irrigação - $\mathrm{CEa}\left(0,3 ; 1,0 ; 1,7\right.$ e $\left.2,4 \mathrm{dS} \mathrm{m}^{-1}\right)$ associado a quatro doses de prolina $(0,5,10$ e $15 \mathrm{mmol}$

1 Discentes de Doutorado, Universidade Federal de Campina Grande, UFCG, Centro de Tecnologia e Recursos Naturais, Campina Grande, PB, Brasil. E-mail: luana lucas15@hotmail.com; engenheiropadua@hotmail.com

2 Prof. Dr., Universidade Federal de Campina Grande, UFCG, Centro de Ciências e Tecnologia Agroalimentar, Pombal, PB, Brasil. E-mail: rgomesnobre@yahoo.com

3 Discentes de Agronomia, UFCG, Centro de Ciências e Tecnologia Agroalimentar, Pombal, PB, Brasil. E-mail:cristiane@1live. com; reynaldo.t16@gmail.com; jutahy.jorge33@gmail.com; felipe12@hotmail.com.

4 Bolsista de Pós-Doutorado Júnior, CNPq, UFCG, Centro de Tecnologia e Recursos Naturais, Campina Grande, PB, Brasil. E-mail: agrosantos@hotmail.com

* Autor for correspondente 
$\mathrm{L}^{-1}$ ). Para o cultivo de plantas enxertadas de goiabeira cv. Paluma pode-se usar água de CEa de $1,1 \mathrm{dS}$ $\mathrm{m}^{-1}$ pois proporciona redução média aceitável de $10 \%$ no crescimento e na atividade fisiológica. Dose média de $8 \mathrm{mmol} \mathrm{L}^{-1}$ de prolina promove aumento no número de folhas e no acúmulo de massa seca. $\mathrm{A}$ interação entre os fatores doses de prolina e níveis de salinidade da água não afetaram o crescimento e fisiologia de plantas enxertadas de goiabeira cv. Paluma, aos 101 dias após o transplantio.

Palavras-chave: Psidium guajava. Salinidade e aminoácidos.

\section{Introduction}

Guava (Psidium guajava L.), a species native to Tropical America, spread all over the Brazilian territory, is characterized as a rustic plant which may adapt to different edaphoclimatic conditions. Its fruits have pleasant taste, high nutritional value and great acceptance in the market, for both fresh consumption and agroindustrial activities. Like other fruit crops with economic importance, guava is widely cultivated in irrigated areas of the semiarid region, among those of highest economic value for Northeast Brazil (CAVALCANTE et al., 2010; OLIVEIRA et al., 2015).

Most of the areas in the semi-arid region are characterized by low annual precipitation, leading to the accumulation of unleached salts, which remain in the soil and water. This results in the need to use saline water in irrigation as an alternative to meet the water demands of the crops, particularly in the drought period, when the wells and dams of the region have higher levels of salts in the water. This activity ultimately affects plant growth, particularly due to the reduction in the water potential of the soil solution, which diminishes water availability to plants (CHAVES et al., 2009), because it interferes with the gradient of variation in water potential between soil and plant, making it unfavorable.

Among several processes affected by salinity, water absorption by plants and gas exchanges are negatively affected because of the reduction in osmotic potential. It has been supposed that this behavior can reduce growth due to the lower absorption of $\mathrm{CO}_{2}$ from the atmosphere, consequently reducing photosynthesis (PRAXEDES et al., 2010).
Regarding the effects of salts, guava is moderately sensitive to soil and water salinity, showing a reduction in its production capacity in sites where irrigation water electrical conductivity exceeds $3.0 \mathrm{dS} \mathrm{m}^{-1}$, and plants are more susceptible to salinity at young age than at the other growth stages (CAVALCANTE et al., 2005; TÁVORA et al., 2001).

Research has found, in response to salt stress, significantly positive correlation between the accumulation of organic solutes or osmolytes (proline, glycine betaine, trehalose, sucrose, among others) and the increase in the tolerance to salt stress in agricultural crops (SÁ et al., 2016; ASHRAF et al., 2011; VERBRUGGEN; HERMANS, 2008). The amino acid proline is a compatible solute in the cytosol, contributes to the intracellular osmotic balance and can also protect cytosolic enzymes when the concentration of ions increases, and consequently maintain water potential and turgor of the cells. Besides being an osmoregulator, proline acts by favoring the balance of redox reactions in stressed cells (LIMA et al., 2016).

In this context, the present study aimed to evaluate physiological and growth responses of grafted plants of guava cv. Paluma, as a function of irrigation with saline water and foliar applications of proline.

\section{Material and Methods}

The experiment was carried from August to December 2016, in a greenhouse (protected environment) at the Center of Sciences and Agri- 
Food Technology of the Federal University of Campina Grande (CCTA/UFCG), Campus of Pombal-PB, whose local geographic coordinates are $6^{\circ} 48^{\prime} 16^{\prime \prime} \mathrm{S}, 37^{\circ} 49^{\prime} 15^{\prime \prime} \mathrm{W}$ at mean altitude of $144 \mathrm{~m}$.

The statistical design adopted was randomized blocks, in $4 \times 4$ factorial scheme (salt concentration $\mathrm{x}$ proline dose), with three replicates and one plant per plot, totaling 48 plants.

Salt concentrations were based on four levels of water electrical conductivity - ECw, 0.3, $1.0,1.7$ and $2.4 \mathrm{dS} \mathrm{m}^{-1}$, and the four proline doses were 0,5 , 10 and $15 \mathrm{mmol} \mathrm{L}^{-1}$, resulting in 16 treatments.

Saline waters were prepared by adding in the local supply water (ECW of $0.3 \mathrm{dS} \mathrm{m}^{-1}$ ) sodium chloride $(\mathrm{NaCl})$, calcium chloride $\left(\mathrm{CaCl}_{2} \cdot 2 \mathrm{H}_{2} \mathrm{O}\right)$ and magnesium chloride $\left(\mathrm{MgCl}_{2} \cdot 6 \mathrm{H}_{2} \mathrm{O}\right)$, at proportion of $7: 2: 1$, which is the predominant ratio in the main sources of water available for irrigation in the Brazilian Northeast region (MEDEIROS, 1992).
The experiment was conducted using the cultivar Paluma as rootstock and scion because it is a vigorous genotype, with easy propagation, tolerant to pests and diseases and one of the most cultivated in Northeast Brazil (MENDONÇA et al., 2011). Guava seedlings were grafted using the cleft method at 8 months after the rootstocks were sown.

Plants were grown in lysimeters with capacity for approximately $12 \mathrm{~L}$, perforated at the bottom where drains were connected and attached to a container to collect drainage water, in order to monitor the drained volume and water consumption by the crop. The lysimeters were filled with a 250-g layer of crushed stone, covering the bottom part, and $12 \mathrm{dm}^{3}$ of soil, a mixture of soil + sand + bovine manure, at percentages of 84,13 and 3\%, respectively.

Physical and chemical characteristics of the substrate (Table 1) were analyzed at the Laboratory of Soils and Plants of CCTA/UFCG, according to the methodology of Claessen (1997).

Table 1. Physical and chemical characteristics of the substrate used in the experiment.

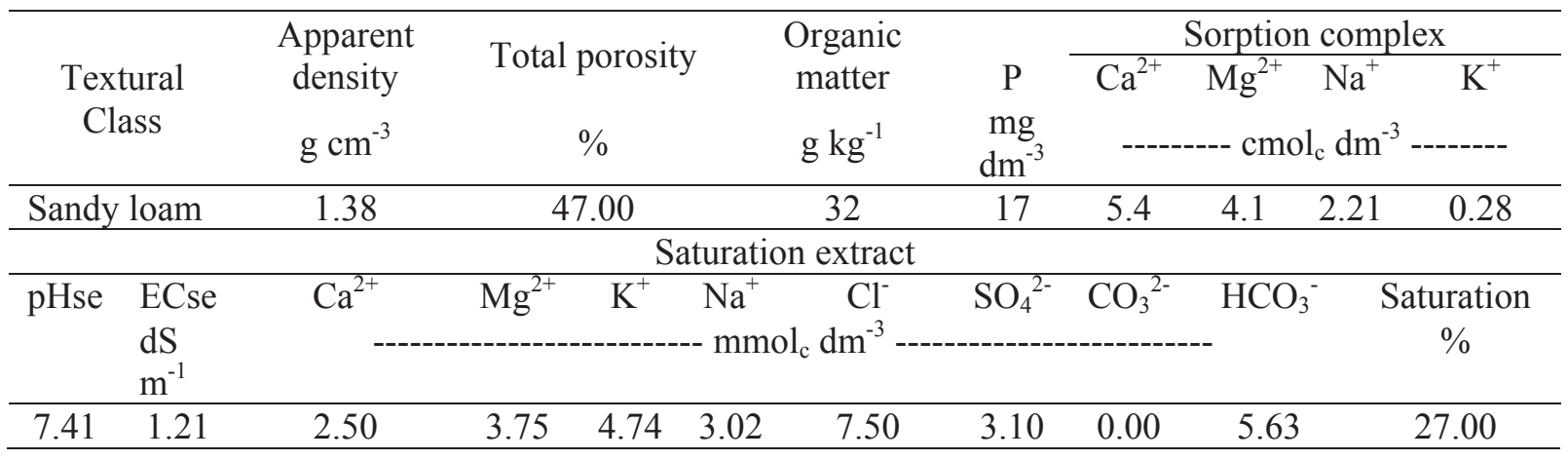

Saline waters began to be applied at 21 days after transplanting the seedlings (DAT) according to the treatments, considering the water needs of the crop, determined by drainage lysimetry. The volume applied was equivalent to that retained in the pots, determined by difference between the volume applied and the volume drained in the previous irrigation. Irrigations were performed based on drainage lysimetry, twice a day, in the early morning and late afternoon. Every 15 days, a leaching fraction of 0.15 was applied, based on the volume applied in this period, to reduce the salinity in the substrate saturation extract.

Proline doses also began to be applied at 21 DAT, every 15 days, according to the treatments. The different quantities of proline $(0 ; 575.65 ; 1,151.30$; $1,726.95 \mathrm{mg} / \mathrm{L}$, which correspond to $0,5,10$ and $15 \mathrm{mmol} / \mathrm{L}$ ) were separately diluted in water from 
the local supply system (ECw of $0.3 \mathrm{dS} \mathrm{m}^{-1}$ ) and applied through foliar spraying.

At 101 DAT, branch length (BL), stem diameter $2 \mathrm{~cm}$ above the grafting point $\left(\mathrm{SD}_{\mathrm{AG}}\right)$, number of leaves (NL) and total dry matter (TDM) were evaluated. In addition, net photosynthesis rate $(A)$, transpiration rate $(E)$, internal $\mathrm{CO}_{2}$ concentration $\left(C_{i}\right)$ and stomatal conductance $(g s)$ were also evaluated in fully developed leaves, using an infrared gas analyzer - IRGA (LCI System, ADC, Hoddesdom).

BL was determined by measuring the branches from the point of attachment on the stem to the apex $(\mathrm{cm}) . \mathrm{SD}_{\mathrm{AG}}$ was determined by a measurement above the grafting point ( $\mathrm{mm}$ ). NL was determined by counting all leaves with fully open lamina. To determine the total dry matter (TDM), the different plant parts (leaves, stem and roots) were separately placed in paper bags properly identified, dried in a forced-air oven at temperature of $65{ }^{\circ} \mathrm{C}$ until constant weight, and weighed.

The results were subjected to analysis of variance by $F$ test at 0.05 and 0.01 probability levels and, in cases of significance, polynomial regression analysis was carried out using the program SISVAR (FERREIRA, 2011).

\section{Results and Discussion}

According to the result of the analysis of variance (Table 2), irrigation water salinity caused significant differences in branch length, stem diameter, number of leaves and total dry matter. Proline doses caused significant effect only on number of leaves and total dry matter. However, the interaction between irrigation water salinity and proline doses had no significant effect on any of the variables evaluated in grafted guava plants, cv. Paluma, at 101 DAT.

Table 2. Summary of the analysis of variance for branch length $(\mathrm{BL})$, stem diameter above the grafting point $\left(\mathrm{SD}_{\mathrm{AG}}\right)$, number of leaves (NL) and total dry matter (TDM) of grafted guava cv. Paluma at 101 days after transplanting - DAT.

\begin{tabular}{cccccc}
\hline \multirow{2}{*}{ Source of variation } & \multirow{2}{*}{$\mathrm{FD}$} & \multicolumn{3}{c}{ Mean squares } \\
\cline { 3 - 6 } & & $\mathrm{BL}$ & $\mathrm{SD}_{\mathrm{AG}}$ & $\mathrm{NL}$ & $\mathrm{TDM}$ \\
\hline ECW $\left(\mathrm{dS} \mathrm{m} \mathrm{m}^{-1}\right)$ & 3 & $152.47^{*}$ & $4.31^{* *}$ & $599.55^{* *}$ & $2018.75^{* *}$ \\
Linear regression & 1 & $437.40^{*}$ & $6.25^{* *}$ & $1706.66^{* *}$ & $5914.70^{* *}$ \\
Quadratic regression & 1 & $8.33^{\mathrm{ns}}$ & $0.07^{\mathrm{ns}}$ & $85.33^{\mathrm{ns}}$ & $71.49^{*}$ \\
Proline (mmol 1-1) & 3 & $130.67^{\mathrm{ns}}$ & $1.05^{\mathrm{ns}}$ & $124.88^{*}$ & $360.13^{*}$ \\
Linear regression & 1 & $27.33^{\mathrm{ns}}$ & $1.72^{\mathrm{ns}}$ & $32.26^{\mathrm{ns}}$ & $7.13^{\mathrm{ns}}$ \\
Quadratic regression & 1 & $33.33^{\mathrm{ns}}$ & $0.32^{\mathrm{ns}}$ & $341.33^{*}$ & $889.58^{*}$ \\
ECW x Proline & 9 & $146.81^{\mathrm{ns}}$ & $1.75^{*}$ & $109.62^{\mathrm{ns}}$ & $171.32^{\mathrm{ns}}$ \\
Blocks & 3 & $60.81^{\mathrm{ns}}$ & $4.70^{* *}$ & $921.33^{* *}$ & $604.82^{*}$ \\
CV (\%) & & 19.25 & 10.70 & 23.84 & 23.68 \\
\hline
\end{tabular}

ns, ${ }^{* *}, *$ respectively not significant, significant at $\mathrm{p}<0.01$ and $\mathrm{p}<0.05$.

Based on the regression analysis for branch length (Figure 1A), a decreasing linear effect was observed with the increase in irrigation water electrical conductivity, which caused reduction of $7.92 \%$ per unit increase in water salinity, i.e., there was a reduction of $16.65 \%(6.94 \mathrm{~cm})$ in plants irrigated with $2.4 \mathrm{dS} \mathrm{m}^{-1}$ water in comparison to those which received $0.3 \mathrm{dS} \mathrm{m}^{-1}$ water. According to Freire et al. (2010), this occurs due to the effect of salinity on cell turgor pressure, because of the reduction of water content in the tissues, which leads to decline in cell wall expansion, causing lower plant growth (SOUZA et al., 2017). 
Figure 1. Branch length (A) and stem diameter (B) of grafted guava cv. Paluma as a function of irrigation water electrical conductivity (ECw), at 101 days after transplanting - DAT.

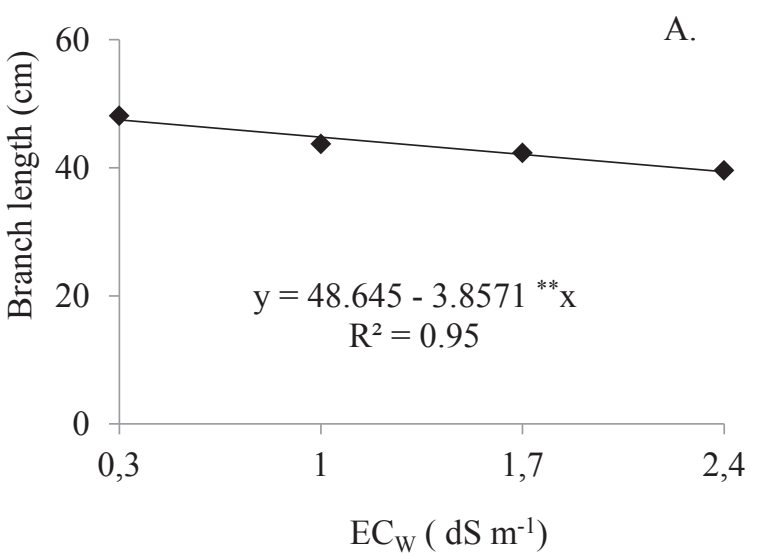

Following the same trend observed for BL, stem diameter above the grafting point (Figure 1B) decreased linearly by $0.95 \mathrm{~mm}(11.25 \%)$ when plants were subjected to the highest salinity level, compared to those under ECw of $0.3 \mathrm{dS} \mathrm{m}^{-1}$. The reduction in $\mathrm{SD}_{\mathrm{AG}}$ probably results from the decrease in the osmotic potential of the soil solution, thus reducing its water potential, which hinders water absorption by the roots. This causes the plant to reduce photosynthesis and metabolic activity for cell division and, consequently, its growth, besides the possibility of occurrence of ionic toxicity (SANTOS et al., 2012), a symptom observed in the plants along the experiment.

Regarding the effects of salinity on the number of leaves of grafted guava (Figure 2A), there was a linear reduction with the increase in irrigation water electrical conductivity. This variable decreased by $14.76 \%$ per unit increase in $\mathrm{ECw}$, which is equivalent to a reduction of $30.99 \%$ (13.71 leaves) in plants subjected to $2.1 \mathrm{dS} \mathrm{m}^{-1}$, compared to those at the

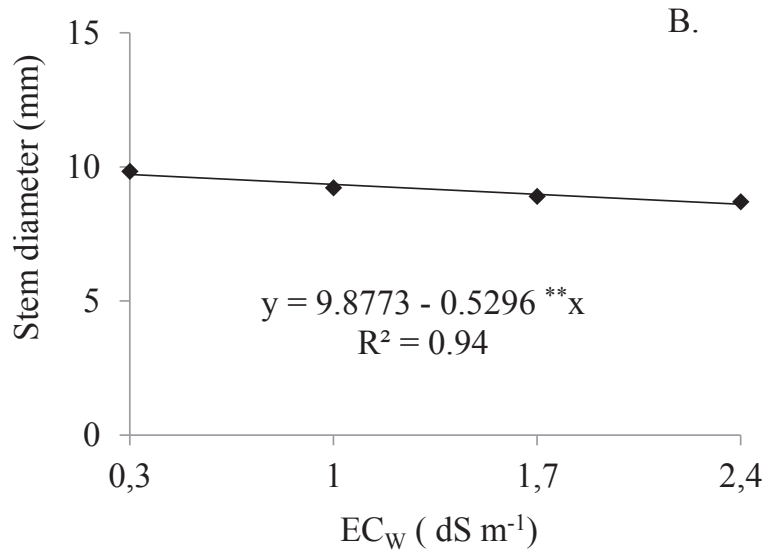

lowest salinity level $\left(0.3 \mathrm{dS} \mathrm{m}^{-1}\right)$. Reduction in the number of leaves in guava is certainly associated with the osmotic factor, which changes the values of water potential. Oliveira et al. (2011) stated that the reduction in NL is related to morphological and anatomical modifications, which aim to reduce losses by transpiration, a fact confirmed in Figure $5 \mathrm{~A}$, which demonstrates a reduction in transpiration with the increase in salinity.

According to Figure 2B, for the number of leaves (NL) at 101 DAT, the data fitted best with a quadratic regression model as a function of the increase in proline doses, and its maximum point (47.31 leaves) was obtained in plants subjected to proline dose of $7 \mathrm{mmol} \mathrm{L}^{-1}$. Foliar application of proline favored the increase in the number of leaves up to the concentration of $7 \mathrm{mmol} \mathrm{L}^{-1}$; from this point on, proline may become toxic, possibly due to alterations in cytosolic $\mathrm{pH}$ and in the state of the redox reactions, causing irreversible damages to the cell membranes of the plants (LIMA et al., 2016). 
Figure 2. Number of leaves of grafted guava cv. Paluma as a function of irrigation water electrical conductivity $-\mathrm{ECw}$ (A) and proline doses (B) at 101 days after transplanting - DAT.

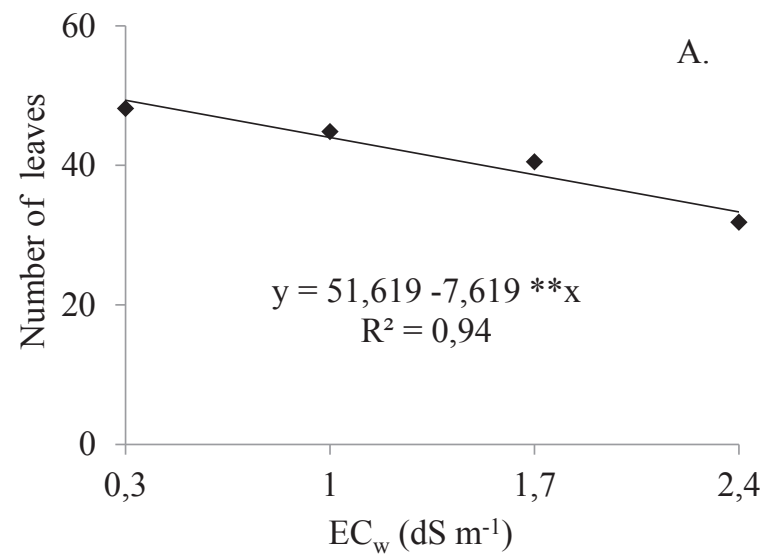

The total dry matter of grafted guava plants was negatively affected by the increase in irrigation water salinity (Figure 3A) and decreased linearly by $19.72 \%$ per unit increase in $\mathrm{ECw}$, a decline of $41.43 \%$ (29.77 g) in plants at the highest ECw (2.1 $\left.\mathrm{dS} \mathrm{m}{ }^{-1}\right)$ compared to those at the lowest ECw $(0.3$ $\left.\mathrm{dS} \mathrm{m}^{-1}\right)$. This fact can be explained by the high

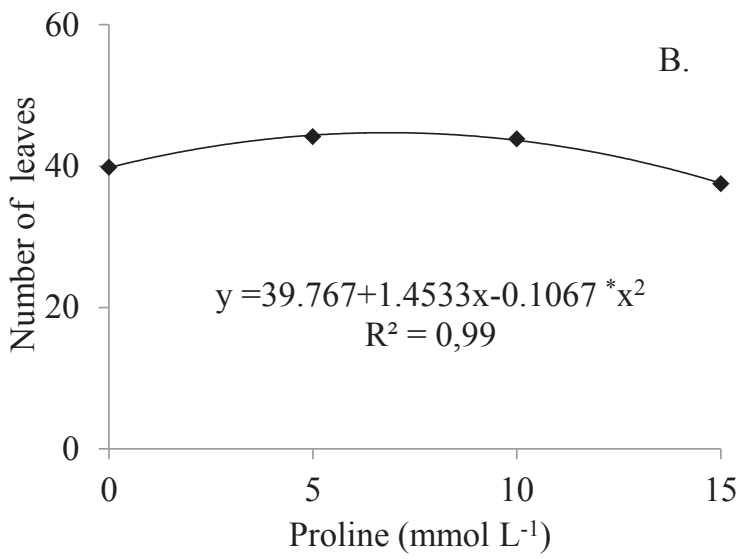

salinity, which reduces the metabolic assimilation rate in the plants and the activity of enzymes responsible for respiration and photosynthesis, thus limiting the obtaining of energy for growth and cell differentiation in tissues, consequently reducing embryo axis elongation and dry matter production (NASCIMENTO et al., 2015).

Figure 3. Total dry matter (TDM) of grafted guava cv. Paluma as a function of irrigation water electrical conductivity - ECw (A) and proline doses (B) at 101 days after transplanting - DAT.

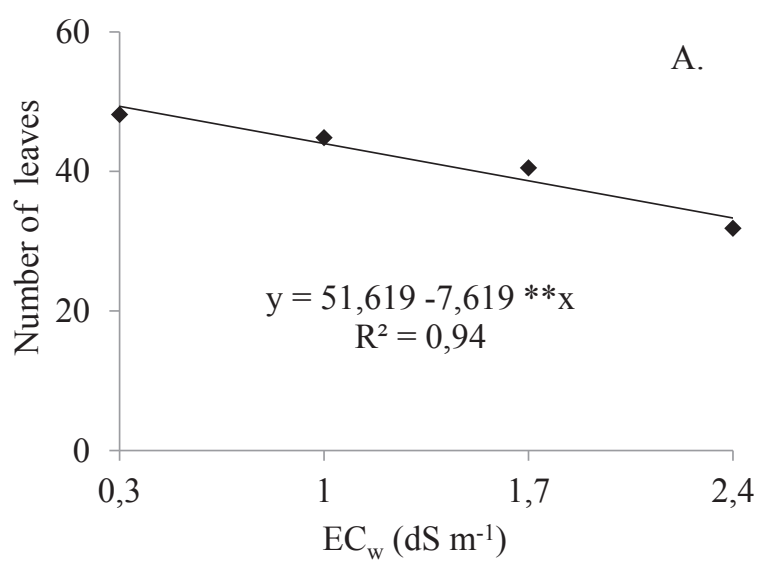

Proline doses had significant effect on total dry matter accumulation (Figure 3B), causing a quadratic behavior, in which the maximum point $(58.11 \mathrm{~g})$ was observed in plants treated with $8 \mathrm{mmol} \mathrm{L}-1$ of proline. This denotes that foliar

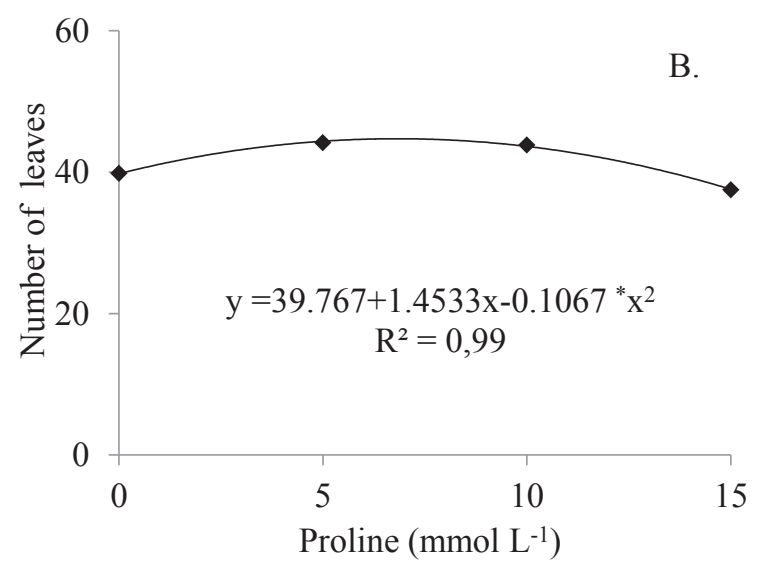

application with adequate amounts of this amino acid can promote higher dry matter production in grafted guava cv. Paluma because, besides the osmoprotectant function against toxic byproducts from the metabolism, resulting from water stress, 
the accumulation of this osmolyte inside the plant can increase osmotic pressure inside the cell, which maintains water absorption and cell turgor pressure, giving continuity to physiological processes, although at lower levels compared with non-stressed plants (MONTEIRO et al., 2014).

Based on the F test summary (Table 3), salinity levels $(\mathrm{ECw})$ had significant effect on stomatal conductance $(g s)$, transpiration rate $(E)$ and net photosynthesis $(A)$ in grafted plants of guava, cv. Paluma. Proline doses and their interaction with $\mathrm{ECw}$ caused no significant effect on the analyzed variables. Contrary to the results of the present study, Lacerda et al. (2012) observed significant effect of proline doses on the physiological variables of the melon crop, evaluating the effect of exogenous proline application $\left(0,5,10\right.$ and $\left.20 \mathrm{mmol} \mathrm{L}^{-1}\right)$ on melon plants irrigated with saline water (ECw: 0.3 and $\left.5.0 \mathrm{dS} \mathrm{m}^{-1}\right)$.

Table 3. Summary of analysis of variance for stomatal conductance $\left(g_{s}\right)$, internal $\mathrm{CO}_{2}$ concentration $\left(C_{i}\right)$, transpiration $(E)$ and net photosynthesis $(A)$ of grafted guava plants at 101 days after transplanting - DAT.

\begin{tabular}{cccccc}
\hline \multirow{2}{*}{ Source of variation } & \multirow{2}{*}{ FD } & \multicolumn{4}{c}{ Mean squares } \\
\cline { 3 - 6 } & & $g_{\mathrm{s}}$ & $C_{\mathrm{i}}$ & $E$ & $A$ \\
\hline ECw $\left(\mathrm{dS} \mathrm{m}^{-1}\right)$ & 4 & $0.004^{* *}$ & $2477.57^{\text {ns }}$ & $2.58^{* *}$ & $10.64^{* *}$ \\
Linear regression & 1 & $0.009^{* *}$ & $1062.60^{\text {ns }}$ & $7.46^{* *}$ & $30.05^{* *}$ \\
Quadratic regression & 1 & $0.001^{\text {n** }}$ & $4582.52^{* *}$ & $0.001^{\text {ns }}$ & $0.32^{\text {ns }}$ \\
Proline $\left(\mathrm{mmol}^{-1}\right)$ & 3 & $0.0005^{\text {ns }}$ & $789.90^{\text {ns }}$ & $0.08^{\text {ns }}$ & $0.42^{\text {ns }}$ \\
Linear regression & 1 & $0.001^{\text {ns }}$ & $1071.03^{\text {ns }}$ & $0.12^{\text {ns }}$ & $0.83^{\text {ns }}$ \\
Quadratic regression & 1 & $0.00005^{\text {ns }}$ & $567.18^{\text {ns }}$ & $0.003^{\text {ns }}$ & $0.19^{\text {ns }}$ \\
ECw x Proline & 12 & $0.00008^{\text {ns }}$ & $461.09^{\text {ns }}$ & $0.08^{\text {ns }}$ & $0.61^{\text {ns }}$ \\
Blocks & 2 & $0.0009^{\text {ns }}$ & $591.64^{\text {ns }}$ & $0.19^{\text {ns }}$ & $0.79^{\text {ns }}$ \\
CV $(\%)$ & - & 27.33 & 11.60 & 30.80 & 17.49 \\
\hline
\end{tabular}

${ }_{\mathrm{ns},}{ }^{* *},{ }^{*}$ respectively not significant, significant at $\mathrm{p}<0.01$ and $\mathrm{p}<0.05$.

For stomatal conductance as a function of the different levels of irrigation water salinity (Figure 4), the increase in ECw levels caused reduction in $g s$, and its maximum value $\left(0.0930 \mathrm{mmol} \mathrm{m}^{-2} \mathrm{~s}^{-1}\right)$ was found at conductivity of $0.3 \mathrm{dS} \mathrm{m}^{-1}$. According to Freire et al. (2014), the increase in irrigation water salinity has a negative effect on stomatal opening, because it increases the resistance to $\mathrm{CO}_{2}$ diffusion, consequently leading to decline in net photosynthesis rate, a fact observed in Figure 5B.
This changes gs, because it influences the turgor of guard cells, which was observed in plants irrigated with $2.4 \mathrm{dS} \mathrm{m}^{-1}$ water. Stomatal conductance decreased from $0.09 \mathrm{~mol} \mathrm{~m}^{-2} \mathrm{~s}^{-1}$, in plants irrigated with low-salinity water, to $0.05 \mathrm{~mol} \mathrm{~m}^{-2} \mathrm{~s}^{-1}$, in plants irrigated with high-salinity water. Sousa et al. (2016) observed reduction in stomatal conductance on the order of $58.57 \%$, in citrus plants subjected to $\mathrm{ECW}$ of $3.0 \mathrm{dS} \mathrm{m}^{-1}$ compared with those irrigated with the lowest salinity level $\left(0.6 \mathrm{dS} \mathrm{m}^{-1}\right)$. 
Figure 4. Stomatal conductance of grafted guava cv. Paluma as a function of irrigation water electrical conductivity $-\mathrm{ECw}$ at 101 days after transplanting - DAT.

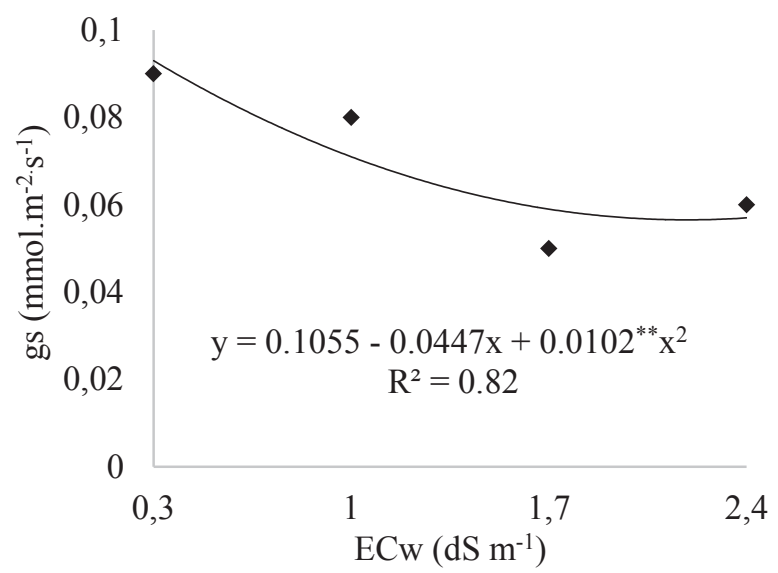

The increase in irrigation water salinity prevents the entry of salts and, therefore, limits reduced plant transpiration, a decrease of $21.83 \%$ at 101 DAT per unit increase in ECw (Figure 5A). Comparing this value with the one estimated at the highest salinity level $\left(2.4 \mathrm{dS} \mathrm{m}^{-1}\right)$, it is possible to observe a reduction of $45.85 \%\left(1.05 \mathrm{mmol} \mathrm{m}^{-2}\right.$ $\left.\mathrm{s}^{-1}\right)$ in transpiration. Reduction in transpiration is caused by the decrease in stomatal opening and can be considered as beneficial to the plant because it is regarded as a mechanism of tolerance to salinity, aiming to reduce the transpiration process, besides regulating the entry of water in the plants, which

the toxicity by specific ions (SILVA et al., 2014). According to Gonçalves et al. (2010), there is a direct relationship between $E$ and $g s$, and the water vapor flux to the atmosphere decreases as the stomata close. Consequently, transpiration decreases and thus stomatal conductance also decreases. This trend was observed in the present study, with reductions of $1.05 \mathrm{mmol} \mathrm{m}^{-2} \mathrm{~s}^{-1}$ in transpiration and $0.03 \mathrm{mmol} \mathrm{m}^{-2}$ $\mathrm{s}^{-1}$ in stomatal conductance between the lowest $(0.3$ $\left.\mathrm{dS} \mathrm{m}{ }^{-1}\right)$ and highest $\left(2.4 \mathrm{dS} \mathrm{m}^{-1}\right)$ levels of salinity.

Figure 5. Transpiration rate $(E)(\mathrm{A})$ and net photosynthesis $(A)(\mathrm{B})$ of grafted guava cv. Paluma as a function of irrigation water electrical conductivity - ECw at 101 days after transplanting - DAT.
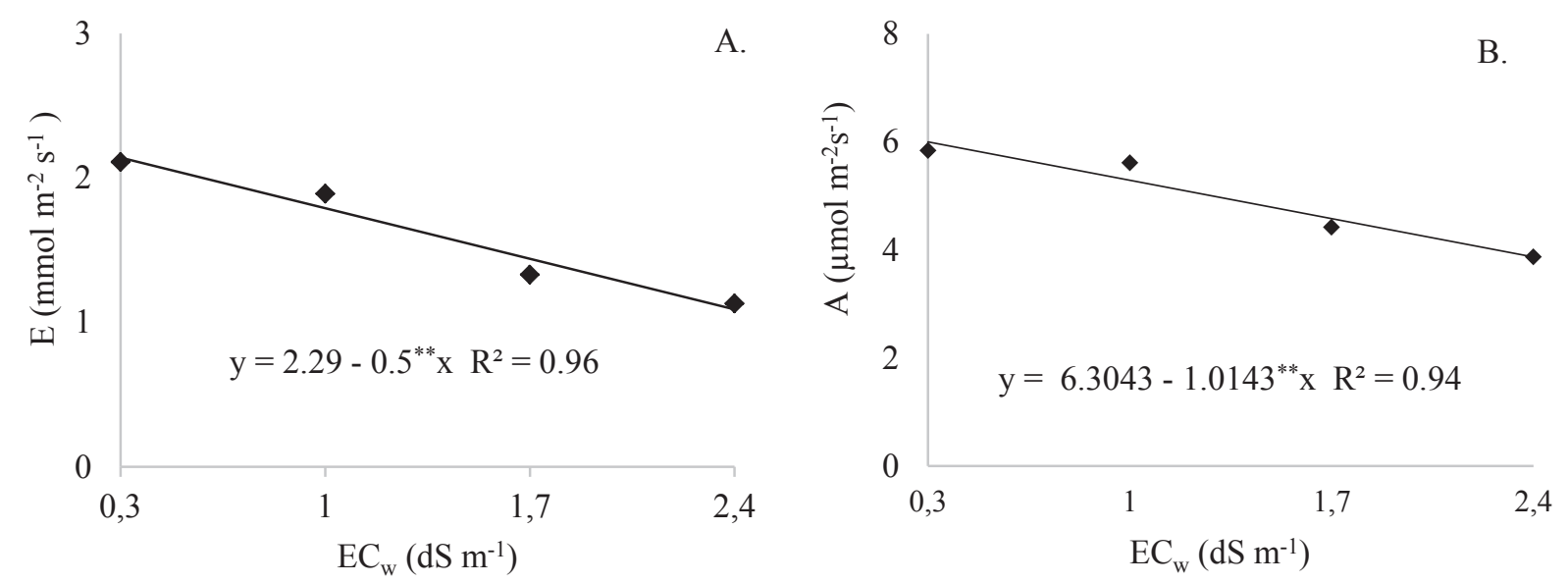
Following the same behavior of transpiration, the net photosynthesis of grafted guava cv. Paluma decreased linearly according to the regression equation (Figure 1B). Its reduction was equal to $16.08 \%$ per unit increase in irrigation water salinity, i.e., a reduction of $2.13011 \mathrm{mmol} \mathrm{m}^{-2} \mathrm{~s}^{-1}(33.78 \%)$ in plants subjected to the $2.4 \mathrm{dS} \mathrm{m}^{-1}$ in comparison to those under $0.3 \mathrm{dS} \mathrm{m}^{-1}$. It can be observed that variations in transpiration and stomatal conductance affected the photosynthetic rate, leading to the conclusion that the saline treatments affected gas exchanges. Additionally, stomatal closure and the consequent reduction in the normal $\mathrm{CO}_{2}$ flux to the carboxylation site is one of the main causes for the reduction in photosynthesis in plants grown under saline conditions (SOARES et al., 2013).

\section{Acknowledgments}

To the Federal University of Campina Grande UFCG.

\section{Conclusions}

Irrigation using water with $\mathrm{ECw}$ of $1.1 \mathrm{dS} \mathrm{m}^{-1}$ leads to acceptable mean reduction of $10 \%$ in the growth and physiological activity of grafted guava, cv. Paluma, until 101 DAT.

Proline dose of $8 \mathrm{mmol} \mathrm{L}^{-1}$ attenuated the negative effects of salinity on the number of leaves and total dry matter of guava plants, 101 days after transplanting.

The interaction between proline doses and water salinity levels did not affect the growth and physiology of grafted guava, cv. Paluma.

\section{References}

ASHRAF, M., AKRAM, N. A., ALQURAINY, F.; FOOLAD, M. R. Drought tolerance: roles of organic osmolytes, growth regulators, and mineral nutrients. Advances in Agronomy, v. 111, p. 249-296, 2011.
CAVALCANTE, L. F.; CAVALCANTE, I. H. L.; PEREIRA, K S. N.; OLIVEIRA, F. A. de; GONDIM, S. C.; ARAÚJO, F. A. R. de. Germination and initial growth of guava plants irrigated with saline water. Revista Brasileira de Engenharia Agrícola e Ambiental, Campina Grande, v. 9, n. 4, p. 515-519, 2005.

CAVALCANTE, L. F.; VIEIRA, M. S. da; SANTOS, A. F. dos; OLIVEIRA, W. M. de, NASCIMENTO, J. A. M. do. Água salina e esterco bovino líquido na formação de mudas de goiabeira cultivar paluma. Revista Brasileira de Fruticultura, Jaboticabal, v. 32, n. 1, p. 251-261, 2010.

CHAVES, M. M.; FLEXAS, J.; PINHEIRO, C. Photosynthesis under drought and salt stress: regulation mechanisms from whole plant to cell. Annals of Botany, England, v. 103, n. 4, p. 551-560, 2009.

CLAESSEN, M. E. C. (Org.). Manual de métodos de análise de solo. 2. ed. rev. atual. Rio de Janeiro: Embrapa CNPS, 1997. 212 p. (Embrapa-CNPS. Documentos, 1).

FERREIRA, D. F. Sisvar: um sistema computacional de análise estatística. Ciência e Agrotecnologia, v. 35, n. 9, p.1039-1042, 2011.

FREIRE, A. L.; PAIVA SARAIVA, V.; MIRANDA, J. R. P. de; BRUNO, G. B.; FREIRE, J. L. D. O.; DIAS, T. J.; CAVALCANTE, L. F.; FERNANDES, P. D.; LIMA NETO, A. J. D. Quantum yield and gas exchange in yellow passion fruit under salinity water, biofertilization and mulch. Revista Ciência Agronômica, Fortaleza, v. 45, n. 1, p. 82-91, 2014.

FREIRE, J. L. D. O.; CAVALCANTE, L. F.; REBEQUI, A. M.; DIAS, T. J.; NUNES, J. C.; CAVALCANTE, Í. H. Atributos qualitativos do maracujá amarelo produzido com água salina, biofertilizante e cobertura morta no solo. Revista Brasileira de Ciências Agrárias, Recife, v.5, n.1, p. 102-110, 2010.

GONÇALVES, E. R.; FERREIRA, V. M.; SILVA, J. V.; ENDRES, L.; BARBOSA, T. P.; DUARTE, W. G. de. Trocas gasosas e fluorescência da clorofila a em variedades de cana-de-açúcar submetidas à deficiência hídrica. Revista Brasileira de Engenharia Agrícola e Ambiental, Campina Grande, v. 14, n. 4, p. 378-386, 2010.

LACERDA, F. H. D.; PEREIRA, F. H. F.; NEVES, D. S. da; BORGES, F. Q. C. da; JÚNIOR, J. E. C. Aplicação exógena de prolina na redução do estresse salino em meloeiro. Revista Verde de Agroecologia e Desenvolvimento Sustentável, Pombal, v. 7, n. 3, p. 218$227,2012$.

LIMA, G. S. de; SANTOS, J. B. dos; SOARES, L. A. A. dos; GHEYI, H. R.; NOBRE, R. G. Irrigação com águas salinas e aplicação de prolina foliar em cultivo de 
pimentão 'All Big. Comunicata Scientiae, Bom Jesus, v. 7, n. 4, p. 513, 2016.

MEDEIROS, J. F. Qualidade da água de irrigação e evolução da salinidade nas propriedades assistidas pelo "GAT" nos Estado do RN, PB e CE. 1992. Dissertação (Mestrado em Engenharia Agrícola) - Universidade Federal da Paraíba, Campina Grande.

MENDONÇA, V. Cultura da goiaba. Mossoró: UFERSA, 2011. $40 \mathrm{p}$.

MONTEIRO, J. G.; CRUZ, F. J. R.; NARDIN, M. B.; SANTOS, D. M. M. dos. Crescimento e conteúdo de prolina em plântulas de guandu submetidas a estresse osmótico e à putrescina exógena. Pesquisa Agropecuária Brasileira, Brasília, v. 49, n. 1, p. 18-25, 2014.

NASCIMENTO, I. B. do; MEDEIROS, J. F. de; ALVES, S. S. V.; CARVALHO, B. L. L. de; SILVA, J. L. A. de. Desenvolvimento inicial da cultura do pimentão influenciado pela salinidade da água de irrigação em dois tipos de solos. Agropecuária Cientifica no Semiárido, Patos, v. 11, n. 1, p. 37-43, 2015.

OLIVEIRA, F. A.; CARRILHO, M. J. S. O.; MEDEIROS, J. F.; MARACAJÁ, P. B.; OLIVEIRA, M.

K. T. Desempenho de cultivares de alface submetidas a diferentes níveis de salinidade da água de irrigação. Revista Brasileira de Engenharia Agrícola e Ambiental, Campina Grande, v. 15, n. 8, p. 771-777, 2011.

OLIVEIRA, F. T. de; HAFLE, O. M.; MENDONÇA, V.; MOREIRA, J. N.; JUNIOR, E. B. P.; ROLIM, H. O. Respostas de porta-enxertos de goiabeira sob diferentes fontes e proporções de materiais orgânicos. Comunicata Scientiae, Bom Jesus, v. 6, n. 1, p. 17, 2015.

PRAXEDES, S. C.; LACERDA, C. F. de; DAMATTA, F. M.; PRISCO, J. T.; GOMES-FILHO, E. Salt tolerance is associated with differences in ion accumulation, biomass allocation and photosynthesis in cowpea cultivars. Journal of Agronomy and Crop Science, Fortaleza, v. 196, n. 3, p. 193-204, 2010.

SÁ, F. V. da S.; LIMA; G. S. de; SANTOS, J. B. dos; GHEYI, H. R.; SOARES, L. A. dos A.; CAVALCANTE, L. F.; PAIVA, E. P. de; Souza, L. de P. Growth and physiological aspects of bell pepper (Capsicum annuum) under saline stress and exogenous application of proline. African Journal of Biotechnology, Nairobi, v. 15, n. 36, p. 1970-1976, 2016.

SANTOS, D. B. dos; FERREIRA, P. A.; OLIVEIRA, F. G. de; BATISTA, R. O.; COSTA, A. C.; CANO, M. A. O. Produção e parâmetros fisiológicos do amendoim em função do estresse salino. Idesia, Idesia, v. 30, n. 2, p. 69-74, 2012.

SILVA, L. A.; BRITO, M. E. B.; SÁ, F. D. S.; MOREIRA, R. C. L.; SOARES FILHO, W. D. S.; FERNANDES, P. D. Mecanismos fisiológicos de percepção do estresse salino de híbridos de porta-enxertos citros em cultivo hidropônico. Revista Brasileira de Engenharia Agrícola e Ambiental, Campina Grande, v. 18, p. 1-7, 2014. Suplemento.

SOARES, L. A.; LIMA, G. S.; NOBRE, R. G.; GHEYI, H. R.; PEREIRA, F. H. F. Fisiologia e acúmulo de fitomassa pela mamoneira submetida a estresse salino e adubação nitrogenada. Revista Verde de Agroecologia e Desenvolvimento Sustentável, Pombal, v. 8, n. 1, p. 247256, 2013.

SOUSA, J. R. M. de; GHEYI, H. R.; BRITO, M. E. B.; XAVIER, D. A.; FREITAS, F. G. de. Trocas gasosas e produção de citros irrigados com águas salinas e adubação nitrogenada. Revista Caatinga, Mossoró, v. 29, n. 2, p. 415-424, 2016.

SOUZA, L. P. de; NOBRE, R. G.; SILVA, E. M.; GHEYI, H. R.; SOARES, L. A. dos Anjos. Produção de portaenxerto de goiabeira cultivado com águas de diferentes salinidades e doses de nitrogênio. Revista Ciência Agronômica, Fortaleza, v. 48, n. 4, p. 596-604, 2017.

TÁVORA, F. J. A. F.; PEREIRA, R. G.; HERNADEZ, F. F. F. Crescimento e relações hídricas em plantas de goiabeira submetidas a estresse salino com $\mathrm{NaCl}$. Revista Brasileira de Fruticultura, Jaboticabal, v. 23, n. 2, p. 441-446, 2001.

VERBRUGGEN, N.; HERMANS, C. Proline accumulation in plants: a review. Amino Acids, v. 35, n. 4, p. 753-759, 2008. 